\title{
Strategies for sustainable growth in JSE-listed companies
}

\author{
C. Eitzen and K. Sartorius* \\ School of Accountancy, University of the Witwatersrand, \\ Johannesburg, Republic of South Africa \\ Kurt.Sartorius@wits.ac.za
}

Received June 2011

\begin{abstract}
Achieving high growth that is sustainable is an elusive goal for all but a few great companies. Despite the relative importance of this topic, limited research has been performed to explain this phenomenon, especially in a South African context. This paper adopts an exploratory approach to investigate some of the variables that influence company growth, as well as their choice of strategy. A mixed method incorporating descriptive statistics, regression analysis and qualitative evaluation, was used to test the research questions. A sample of 202 JSE companies indicated $28 \%$ were high growth entities, 39\% medium growth and 33\% achieved growth of less than $10 \%$. A further survey of 30 Chief Executive Officers (CEO) indicated that they believed the top five growth drivers were acquisitions, managerial talent, operational efficiency, an entrepreneurial flair (low growth companies excluded) and the development of networks and partnerships. The respondents, however, ranked the number and importance of these growth drivers very differently with high growth companies citing a broader range of growth drivers than the other respondents. Quite surprisingly, the respondents appear to have underestimated the importance of industry and economy effects. Furthermore, high growth companies appeared to develop a broader spectrum of strategies that were more likely to be linked to their choice of growth driver. Interestingly, high growth companies were the only respondents to develop formal partnership and incentive strategies. In conclusion, the results re-enforce the impression that successful organizations develop a multiplicity of strategies that are always underpinned by operational efficiency.
\end{abstract}

*To whom all correspondence should be addressed.

\section{Introduction}

Sustaining business growth is one of the key challenges that business leaders face (McGrath \& MacMillan, 2005; Smit, Thompson, \& Viguerie, 2005; Zook, 2004; Rijamampianina, Abratt \& February, 2003; Gertz \& Baptista, 1995). In recent years there has been increased interest in growth as a performance variable (Moreno \& Casillas, 2008; Salojarvi, Furu \& Sveiby, 2005; Covin, Slevin, \& Covin, 1990). Jeff Immelt has especially raised the critical importance of growth since he has taken over the reins of General Electric from Jack Welch. He told GE's top managers at an annual meeting in Boca Raton, Florida that: "Another decade of 4\% growth and GE will cease to be a great company. But if we can spur our growth rate without losing our productivity edge, GE will keep being the most admired company into the next century." (Stewart, 2006: 60).

Sustainable high growth is the difference between an average company and a great one, yet, the achievement of this phenomenon is arguably one of the most difficult business challenges (Joachimsthaler, 2007; Harvard Management Update, 1996). Gertz and Baptista (1995) report that from 1983 to 1993 only 30\% of Fortune 1000 companies managed 10\% compound annual growth in revenues. The difficulty of achieving high growth is further underlined by the performance of the Fortune 500
Industrials and Service that only grew at an inflationadjusted compound annual growth rate ("CAGR") of $0,33 \%$ and $2,2 \%$ respectively compared to the U.S. economy as a whole which grew at 2,8\% (Gertz \& Baptista, 1995).

Despite both the importance and difficulty of achieving sustainable growth, there is little guidance in the academic literature in terms of the identification of specific business practices, competitive tactics and strategies associated with the achievement of growth over the long-term (Covin et al., 1990). In fact, growth constitutes one of the least studied dimensions of performance within the field of management, as compared to other performance variables such as profitability (Moreno \& Casillas, 2008; Porter, 1990, Rumelt, 1984). There is even less academic literature about growth in a South African context. There is, however, consensus that growth is not a random or chance event, but is associated with specific firm attributes and behaviours (Perren, 1999a \& 1999b).

The objective of the study is to contribute to a better understanding of the variables that promote sustained company growth. In particular, this study aims to expand the understanding of growth in a South African context by examining the growth drivers, strategies and sources of growth for a sample of JSE-listed companies who have achieved a range of growth rates over a sustained period. 
More specifically the following research problems will be investigated:

1. What was the ratio of high growth companies to low growth companies on the JSE on an industry basis during the period 2000-2006?

2. Do specific variables characterise high growth JSE-listed firms?

3. Do high growth JSE-listed firms have different strategies to low growth JSE-listed firms?

The importance of understanding the drivers of company growth has been pursued in the literature for a number of decades (Harvard Management Update, 1996). In this regard, the paper makes a contribution in a South African and developing country context. The remainder of this article is set out as follows: In Section 2, the drivers of growth are discussed. In Section 3, the method and data are outlined. Section 4 and 5 present and discuss the results. Finally, in Section 6, the paper is concluded and some recommendations are suggested.

\section{Drivers of growth}

The growth of a business is assumed as an obvious goal in most corporate finance literature (Poulos, 2006), and is recognised as one of the key challenges business leaders face (McGrath \& MacMillan, 2005; Rijamampianina et al., 2003). A study conducted by Kroeger, Traem and Rockenhaeuser (2000) asked over 640 CEO's (mainly from Europe) to explain "Why should a company grow?" The results were as follows:

Achieve superior brand recognition:

Improve cost position:

Attract strong alliance partners:

Gain better access to capital:

Attract superior people:

Raise profits:

Obtain a superior strategic position:

Generate superior value:

Some of the significant benefits of growth include obtaining superior strategic positioning and generating superior value. This is consistent with research which claims that there is a premium placed on companies that demonstrate an ability to deliver on superior, sustainable growth expectations (Stewart, 2006; Jonash, 2005). While it is not disputed that growth provides many benefits, the source or driver of this growth is not well understood. The remainder of this section, illustrated by Figure 1, examines a series of endogenous and exogenous drivers of growth. In this regard, the endogenous drivers of growth include resources, motivation and strategy whilst the exogenous drivers incorporate industry and economy level effects that influence demand and supply.

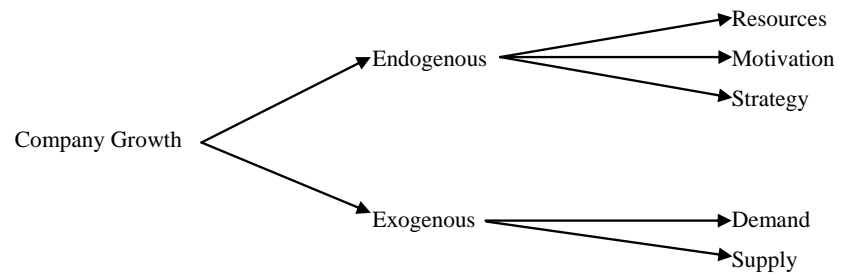

Figure 1: The drivers of growth

\section{Endogenous}

The endogenous drivers of growth include the resources of a company, its level of motivation to achieve sustained growth and its choice and execution of strategy.

\section{Resources}

The resource based view of the firm proposes that sustained competitive advantage is created by the unique resources and capabilities of a firm in its environment (Barney, 1995). According to this paradigm, the microeconomic equilibrium where homogenous firms make zero profit can be overcome if the following two conditions are met (Rumelt, 1984), firstly the firm holds superior resources and secondly these resources are not easily diffused throughout the industry. This idea can be likened to Porter's (1990) concept of barriers to entry. Applying these ideas in the context of growth, suggests that superior or unique resources will act as an effective driver of sustainable growth. The key resources to support sustainable growth include; strategic assets, managerial talent, a talent incubator, happy people and networks/key strategic relationships.

Hamel (2000) identified strategic assets as one of the three foundations necessary for competitive advantage. In this regard, his definition of strategic assets included physical assets, brands and customer relationships that are unique and which provide a competitive advantage over the company's rivals. In addition, it is crucial to have the right people in the right roles to lead and grow the business especially during the periodic upheavals which all businesses are likely to encounter (Cohn, Khurana \& Reeves, 2005). Managerial talent was identified by Edith Penrose (1959) and many other writers (Slater, 1980; Barringer \& Jones, 2004) as the most significant limitation on a firm's growth. Ultimately, a firm's growth is constrained by its ability to find, train and absorb new management of sufficient quality who can administer and accommodate its growth (Slater, 1980; Barringer \& Jones, 2004). Furthermore, talent encompasses the skills, knowledge, technical know-how and ability that resides in people. As managerial talent is a scarce resource, successful companies need to ensure that they have a reliable supply of talent in order to ensure long-term growth. An effective talent development programme provides a company with a long-term competitive edge which is more cheaply sourced inside the company than outside. In this regard, an inspired business model and well-aligned business processes will not compensate for an absence of adequate human capabilities (Diong \& Choo, 2008).

A happy, motivated and engaged workforce is also believed to be a powerful driver of growth. Although, the linkage 
between staff morale and motivation and the success of the firm is one which appears logical, it is difficult to measure and quantify (Pugh, Dietz, Wiley \& Brooks, 1993). A further growth driver appears to be the careful cultivation of strategic alliances and networks that can be used to leverage management capacity and firm resources (Barringer, Jones $\&$ Lewis, 1998). The use of networks refers to the conscious effort by growth-seeking firms to establish long-term relationships with other firms in order to obtain and sustain a competitive advantage (Jarillo 1989). Growth-seeking firms, therefore, use networks to leverage the resources of their network partners in order to pursue opportunities that would normally not be possible due to their own limitations (Jarillo, 1989).

\section{Motivation}

The specific motivation to grow is an essential precursor to growth. It is this motivation to be great which sets companies apart from their competitors and is posited to be a valuable driver of growth. (Penrose, 1959; Barringer \& Jones, 2004) In this regard, there is an argument that suggests that the ideal rate at which a firm should grow is often compromised by lack of motivation. Furthermore, empirical evidence indicates that rapid-growth firms emphasised a "commitment to growth" as compared to normal or low growth firms. Rapid-growth firms were also found to highlight their continued growth intentions, while this was not done by comparable slower growing firms. While, this motivation to grow can manifest itself in a number of ways, it is, however, vital that a "focus on growth" is maintained by the company's leaders (Laurie, Doz \& Sheer, 2006; Barringer \& Jones, 2004). In addition, the leadership of this growth focus is an important driver of growth (Collins, 2001) that needs to be communicated and instilled in all staff throughout the company. Arguably the most effective way of communicating the importance of growth is through an effective performance measurement system (Kaplan \& Norton, 1992; 2007) that identifies what needs to be done to grow. Relentlessly doing these things is also key to growth (Collins, 2001).

\section{Strategy}

Strategy aligns the motivation of a firm with the deployment of its resources. In this context, strategy determines the path chosen to create growth. Within the context of strategy, executives need to make a choice of strategic focus which could either be on market penetration, product development, market development, diversification or a combination of these proposed four alternatives (Ansoff, 1968). Within each of the four strategic choices, companies can achieve growth organically, by means of acquisition or a combination approach. Six specific strategies are identified that could influence sustained company growth. The first strategy involves increasing value through select customers (McGrath \& MacMillan, 2005; Mascarenhas, Kumaraswarny \& Baveja, 2002; Harvard Management Update, 1996; Gertz \& Baptista, 1995). This strategy involves knowing everything about the base of carefully selected customers and their needs. The company focuses on serving those needs with intense dedication in order to transform the customer experience (Reichheld, 2003; Zook
\& Allen, 2003), as well as increasing customer demand which is strongly linked to company growth (Iudanov, 2007). The second strategy focuses on becoming exceptionally effective at developing large numbers of new products that offer superior value to customers (McGrath \& MacMillan, 2005; Zook \& Allen, 2003; Mascarenhas et al., 2002; Harvard Management Update, 1996; Gertz \& Baptista, 1995). This strategy necessitates the development of the people and processes to enable the rapid development of new, value-adding products. Innovation is a powerful driver of growth. The innovation of new products and processes is even more powerful when it is extended to families or platforms of related new products and services. This paradigm helps identify all the synergies and related benefits of a new idea (Diong \& Choo, 2008; Kelley \& Littman, 2006; Jonash, 2005; Kanter, 2006; Stewart, 2006). In fact Kelly and Litman (2006:3) comment that "Innovation is now recognised as the single most important ingredient in any modern economy".

The third strategy attempts distribution innovation (Mascarenhas et al., 2002; Harvard Management Update, 1996; Gertz \& Baptista, 1995). This strategy focuses on finding and developing the most effective ways to connect customers with the company's products and services. The fourth strategy involves monopoly/first-mover advantage (Zook \& Allen, 2003; Mascarenhas et al., 2002; Harvard Management Update, 1996). This strategy involves establishing control of a market and then growing as it grows. Control of the market may be established as a result of first-mover advantage or through anti-competitive means. This strategy is unlikely to be effective in markets where there are not extreme barriers to entry or where there are vigilant competition authorities. The fifth strategy is growth by means of acquisitions (Mascarenhas et al., 2002). The acquisition strategy involves acquiring and consolidating firms in order to increase market share and growth. The sixth strategy, an "adjacent space strategy" (Zook, 2004; Zook \& Allen, 2003), encompasses many of the ideas above, and involves pushing out the boundaries of a company's core business into an adjacent space. The adjacent space referred to can encompass expanding along the value chain, growing new products and services, using new distribution channels and entering new geographies. Finally, this strategy could involve addressing new customer segments, often by modifying a proven product or technology or moving into the "white space" with a new business built around a strong capability (Zook \& Allen, 2003).

\section{Organic versus acquisition}

Organic and acquisition growth have both been widely used by companies who have demonstrated superior growth. However, organic growth is perceived to be superior to acquisitive growth, and past research by Jonash (2005) has demonstrated a strong positive correlation between a company's effective focus on organic growth and future shareholder returns. In contrast, a great deal of research indicates that acquisitions destroy value in the majority of transactions (Laurie et al., 2006), although this conclusion is refuted by other researchers such as Bruner (2002). 


\section{A simple captivating business model}

A simple captivating business model has also been identified as a means to achieve sustainable growth. While an effective, and carefully designed business model is critical for success and growth (Diong \& Choo, 2008), Hess (2007) discovered in his comprehensive study on organic growth that it was companies with simple, easy to understand and captivating business models that significantly outperformed their competitors. The execution of company strategy is also vital to secure sustainable growth. Many firms have impressive plans setting out the firm's strategy, yet very few execute their strategy effectively. "The high ...growth companies generally do not have unique strategies, products or services, nor are they market leading innovators. But they are execution champions - day after day, they have figured out how to get consistent high-quality performance from their people" (Hess, 2007:161).

\section{Repeatable strategy}

Expertise in creating repeatable growth processes is also an important means to ensure sustainable growth. Zook and Allen (2003) conducted a five-year study of corporate growth involving 1,850 companies. One of their key findings was that companies who consistently outgrow their rivals do so by developing processes in order to grow in predictable, repeatable ways. By formalising the growth process into a repeatable formula, companies can achieve higher success rates in what is normally a complex, experimental and chaotic process. The repeatability of the process allows companies to systematize the growth and take advantage of learning-curve effects (Zook \& Allen, 2003).

\section{Entrepreneurship}

Entrepreneurship is important in creating demand and has been defined as being primarily motivated by the pursuit of opportunities, as opposed to those managers exclusively concerned with the efficient management of resources already controlled by the firm (Stevenson \& Jarillo, 1990). As a result of this pursuit of opportunity, high growth tends to be associated with a firm's entrepreneurial behaviour (Brown, Davidson \& Wiklund, 2001; Stevenson \& Jarillo, 1990; Jarillo, 1989). In fact, growth is considered a logical consequence of innovative, proactive and risk-taking behaviour on the part of the firm, as these are dimensions which define entrepreneurship (Gertz \& Baptista, 1995; Moreno \& Casillas, 2008).

\section{Exogenous variables}

This section examines exogenous influences on demand and supply.

\section{Demand}

Demand is intricately linked to the economy and industry in which a company operates. If the country or industry a company operates in is growing, the company is likely to grow. In fact, historically, it was thought that growth was the preserve of companies operating in growth industries (Mascarenhas et al., 2002; Gertz \& Baptista, 1995). For example, a study by Smit et al. (2005), which examined the performance of the 100 largest companies in the United States over the period 1994 - 2003, found a disproportionately large number of high growth companies concentrated in four sectors: financial services, health care, high tech and retailing. Smit et al. (2005) conclude that this concentration is logical considering that these sectors or markets, and segments within them, offer favourable growth environments supported by established trends: aging populations, rapid product or format innovation, deregulation and consolidation (Smit et al., 2005).

\section{Supply}

Jack Welch once said that the 1980's would be a "whiteknuckle" decade of intensifying industrial competition and that the 1990's would be tougher still. The former General Electric chairman was proved right, and the new millennium has seen competition intensify even further. The rate at which companies lose their leadership positions doubled in the 20 years prior to the mid-1990's. This new intense level of competition is characterised by new technologies which have eclipsed long-established industry champions, and nimbler competitors with sharper value propositions and lower costs (Huyett \& Viguerie, 2005). Porter (2001) shows how intense competition reduces industry attractiveness and suggests an inverse relationship between the level of competition and the growth rate in a specific industry.

\section{Data and method}

A combination of methods have been used to test the research questions. In this regard, descriptive analysis is used to test the first research questions. A combination of descriptive analysis and a multiple regression model is used to test the second research question and qualitative analysis is used to test the third research question.

\section{The first research question}

The data for the first research question, namely what is the ratio of high growth companies to low growth companies on the JSE on an industry basis for the period 2000 - 2006, was obtained from the BFA McGregor Blink ("Blink") database. Details of company revenue, earnings attributable to shareholders, as well as industry, super sector and subsector was extracted from the database for the period $2000-2006$. This study only focused on companies listed on the main board of the JSE and excluded AltX-listed companies, as well as companies listed on the Development Capital and Venture Capital boards. Companies which were not listed on the JSE for the full period $2000-2006$ or for which data was not available on the Blink database were excluded from the sample. This resulted in a sample of 202 companies, after excluding 120 companies for the reasons described above. Growth for the purposes of this study was defined as:

Growth $=\frac{\left(\sqrt[n-1]{\frac{a}{b}}-1\right)+\left(\sqrt[n-1]{\frac{c}{d}}-1\right)}{2}$

where: 
$\mathrm{a}=$ Revenue in 2006

$\mathrm{b}=$ Revenue in 2000

$\mathrm{c}=$ Earnings attributable to ordinary shareholders in 2006

$\mathrm{d}=$ Earnings attributable to ordinary shareholders in 2000

$\mathrm{n}=$ Number of data points i.e. 2000 to $2006=7(\mathrm{n}-1=6)$

Companies which achieved an Average Growth Rate in excess of $25 \%$ were classified as high growth companies, while companies which achieved an Average Growth Rate of $10 \%$ and less were classified as low growth companies. Average growth companies were defined as those companies which achieved Average Growth Rates between $10 \%$ and $25 \%$. A ranked summary of the average industry subsector growth rates was presented. A count of the number of high growth, average growth, low growth and excluded companies was developed for each industry subsector of the JSE.

\section{The second research question}

The second research question investigated a range of variables that could be linked to company growth? For the purposes of collecting data a survey and interview process was undertaken. A random sample of companies, with varying levels of revenue and earnings growth, was selected from the total population of 202 companies identified in the first research question. The CEO's of each of the companies forming part of the random sample were identified by perusing the company's website. The executives of these companies were contacted telephonically in order to establish whether they would be willing to participate in the research study. Those executives who were unwilling to participate were eliminated from the sample. A final sample of 30 executives agreed to participate in the research study by completing a survey and participating in an interview. Although the sample size of 30 is limited, the reliability is increased because only the opinions of experts were recorded (Lenth, 2001; Leedy \& Ormrod, 2001). A summary of the sample companies and their industry subsector is provided in Appendix 1.

In order to amplify the choice of growth variables included in the survey, preliminary interviews were conducted with a small sample of JSE-listed company executives. The findings of the preliminary interviews, together with the evidence provided by the literature, were used to finalize the survey variables. In this regard, the executives of the sample companies were requested to allocate 100 points between the 23 identified growth variables, as well as any other growth drivers identified by the executives who they believe contributed to the growth of their company during the survey period. Descriptive analysis was then used to determine the relative importance of the growth drivers. A pilot test was performed to increase the success of the study (Pirow, 1990).

In order to validate the allocation of the 100 points in the survey, a secondary check was used to correlate executives' choice of rating using a Likert scale or other appropriate measure. The information on these proxy variables was obtained through: additional questions posed to the executives; information from the Blink database; as well as information obtained from the companies' annual reports.
This second method of quantifying the importance of growth drivers used a multiple regression model as the basis for determining significant predictors. .

\section{The third research question}

The information for the third research question, namely whether high growth JSE-listed firms have different strategies to low growth JSE-listed firms, was obtained from interviews with executives from the sample companies as described above. Detailed interviews were also undertaken to obtain additional information relating to the choice of growth variables and company strategy. The Interviews were used as a complement to the survey because of the complex nature of company growth and strategy formulation (Leedy \& Ormrod, 2001). Detailed notes were taken during the interviews and, with the interviewee's permission, the interviews were recorded and transcribed. The transcripts of the interviews with the sample company executives were examined and analysed to identify key themes regarding the various growth drivers and their importance in the context of sustainable company growth. The analysis into key themes was performed on the transcribed data using content analysis that was used to identify patterns and themes in open ended data (Leedy \& Ormrod, 2001). This method allowed the study to explore a wide range of variables which contributed to strategy selection. In addition, the third research question was investigated through the evaluation of secondary data including press articles and annual reports during the period $2000-2006$. A combination of data was therefore assembled and investigated using descriptive statistics and qualitative reasoning to investigate whether there was a difference in the strategies adopted by high, average and low growth firms.

The limitations of the study include an exploratory, subjective approach that raises as many questions as it answers. The findings, moreover, are influenced by the opinions and perspectives of the current executives rather than those who may have been responsible during the stated study period. In addition, the research only investigates the growth drivers and strategies of limited sample of JSE-listed companies.

\section{Results}

In this section, the results for the three research questions are presented and discussed. These questions include the ratio of high growth to low growth JSE-listed companies, whether specific variables characterize high growth JSElisted firms and whether different strategies are adopted by high growth JSE-listed firms from low growth JSE-listed firms.

\section{Ratio of high growth to low growth companies}

The proportion of high growth, medium growth and low growth companies is illustrated in Table 1 below. A more detailed analysis of the average CAGR per industry is summarised in Appendix 2. 
Table 1: Proportion of high growth, average growth and low growth JSE-listed companies

\begin{tabular}{l|c|c|c}
\hline Description & Growth Range & $\begin{array}{c}\text { Number of JSE-listed } \\
\text { Companies }\end{array}$ & $\begin{array}{c}\text { Proportion of Total } \\
\text { Companies }\end{array}$ \\
\hline Low Growth Companies & Below 10\% & 67 & $33,20 \%$ \\
\hline Average Growth Companies & $10 \%-25 \%$ & 78 & $38,60 \%$ \\
\hline High Growth Companies & Above 25\% & 57 & $28,20 \%$ \\
\hline Total Companies & & $\mathbf{2 0 2}$ & $\mathbf{1 0 0 \%}$ \\
\hline
\end{tabular}

Further analysis of industry growth, illustrated in Figure 2, summarises the annual real growth rates, contribution to GDP and the size of the various industries over the period 2000 - 2006. In this regard, the construction industry grew the fastest at $14.37 \%$ per annum, followed by finance, real estate and business services $(8.55 \%)$ and transport, storage and communication, while agriculture, forestry and fishing recorded the slowest growth at $0.04 \%$. These growth rates are reflected in the industry subsector growth rates. For example, banks grew in nominal terms at an average of $13.9 \%$ which is close to the average shown in Figure 2 for the finance, real estate and business services industry, after being adjusted for inflation. The excellent growth of the Transport, Storage and Communication industries is reflected in the growth of the Marine Transportation, Trucking and Transportation Services subsectors. The listed Farming and Fishing subsector far outperformed the industry as a whole which may reflect that the quality of listed agricultural players are generally higher than nonlisted players and, as a result, are able to grow in excess of the industry growth rate.

The growth rates of many subsectors appear logical and consistent with perceptions of how industries performed over the study period. For example, it is no surprise that the
Steel and General Mining subsectors performed well considering the recent commodity super-cycle.

Furthermore the high growth of the Marine Transportation subsector (which consists only of Grindrod) is consistent with the global consumer and commodity boom over the later years of the study period which were significant drivers of increased shipping activity.

The subsector which achieved the highest growth, namely Equity Investment Instruments, consists of HCI, Brimstone and Eureka. While Eureka experienced fairly disappointing growth, it is only a minor contributor to the performance of the subsector as compared with HCI and Brimstone which both enjoyed phenomenal growth. These two entities also attest to the wealth that has been created in some BEE investment companies which have made successful investments. Finally, the poor growth performance of the Brewers and Travel \& Tourism subsectors was unexpected, however, this may not reflect the industry as a whole because the performance of only two companies in each of these subsectors have been reflected.

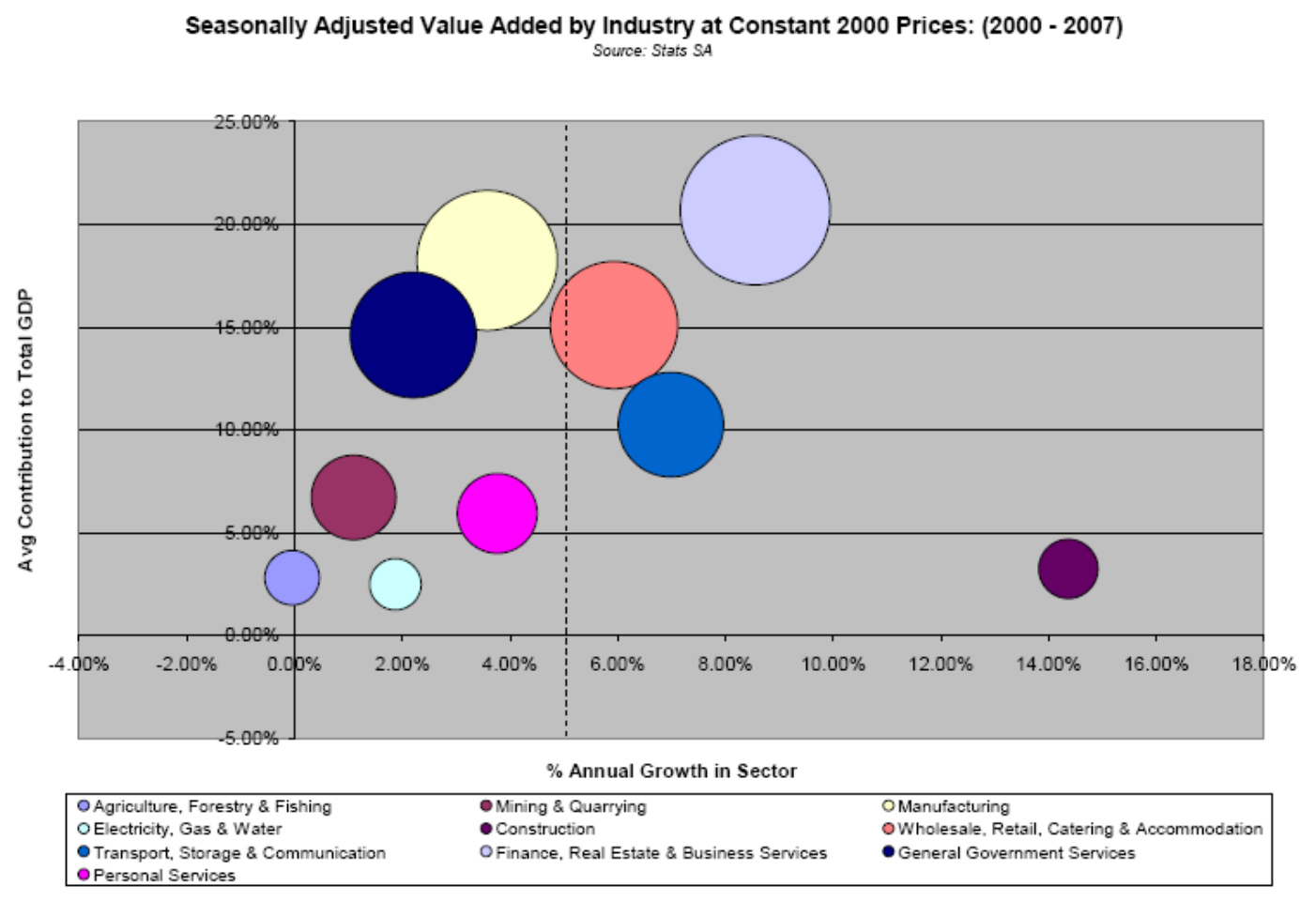

Source: Department of Agriculture and Land Reform; 2008:2

Figure 2: Average size and growth of sectors within the SA economy 


\section{Growth drivers}

The most important drivers of company growth are ranked and summarised in Table 2. In this regard, the mean score for 24 growth drivers indicates high and low growth companies rated certain drivers significantly differently. For example, High growth companies rated entrepreneurship as an important growth variable whereas low growth companies were much less enthusiastic. Conversely, low growth companies rated excellent strategy execution much higher than medium and high growth companies. Interestingly, high and medium growth companies also appeared to include a formal focus on growth compared to the low growth companies. Exogenous influences like the GDP growth rate, the level of competition and regulation were regarded across the board as being less important than a wide range of endogenous variables.

The mean score for each growth driver for high, average and low growth companies is further illustrated in Figure 3. It is interesting to note low growth companies placed far greater reliance on acquisitions, excellent execution and managerial talent than their higher growth counterparts.
Conversely, higher growth companies placed more emphasis on a happy workforce, a simple captivating strategic plan and the incubation of talent. The executives of high growth companies ranked strategy, acquisitions and entrepreneurship as the most significant drivers of growth; average growth companies ranked managerial talent, innovation and strategy highest, while low growth company executives emphasise excellent execution, acquisitions and managerial talent as the critical growth drivers. It is interesting to note that amongst high growth companies, the 100 points are more dispersed with most of the growth drivers receiving a sizable allocation of the points. In contrast, the low growth companies allocated most of the 100 points to a limited number of the growth drivers (the top 3 growth drivers received $40 \%$ of the points), and many other growth drivers received an insignificant allocation. This is perhaps an indication that high growth companies are more likely to identify and recognize the complex web of drivers influencing their firms and industries.

Table 2: Ranked summary of growth drivers per mean score

\begin{tabular}{|c|c|c|c|c|}
\hline Growth Drivers & All Companies & $\begin{array}{c}\text { High growth } \\
\text { companies }\end{array}$ & $\begin{array}{c}\text { Average growth } \\
\text { companies }\end{array}$ & $\begin{array}{c}\text { Low growth } \\
\text { companies }\end{array}$ \\
\hline Acquisitions & 8,67 & 8,44 & 5,94 & 13,80 \\
\hline Strategy & 8,27 & 8,97 & 7,19 & 7,60 \\
\hline Managerial Talent & 7,53 & 6,16 & 8,13 & 11,20 \\
\hline Excellent execution & 7,35 & 6,74 & 4,13 & 14,60 \\
\hline Entrepreneurship & 5,93 & 7,25 & 5,06 & 2,80 \\
\hline Key Strategic Relationships & 5,65 & 6,09 & 4,75 & 5,60 \\
\hline Leadership & 5,63 & 5,75 & 6,25 & 4,20 \\
\hline Access to capital & 5,52 & 4,88 & 5,81 & 7,20 \\
\hline Innovation & 5,40 & 3,82 & 7,25 & 7,80 \\
\hline Focus on growth & 5,10 & 6,53 & 5,13 & 0,20 \\
\hline Happy people & 3,92 & 4,41 & 4,69 & 1,00 \\
\hline Simple, captivating business model & 3,61 & 3,96 & 3,63 & 2,40 \\
\hline Knowledge of customers & 3,55 & 3,38 & 3,00 & 5,00 \\
\hline Customer enthusiasm & 3,12 & 3,21 & 3,75 & 1,80 \\
\hline Discipline & 3,03 & 2,97 & 3,44 & 2,60 \\
\hline Geographical expansion & 2,95 & 2,50 & 4,13 & 2,60 \\
\hline Effective performance measurement & 2,85 & 2,82 & 3,06 & 2,60 \\
\hline Talent incubator & 2,83 & 2,41 & 5,25 & 0,40 \\
\hline Industry growth & 2,80 & 2,82 & 3,13 & 2,20 \\
\hline GDP growth & 2,28 & 2,41 & 1,31 & 3,40 \\
\hline Repeatable growth processes & 1,87 & 2,26 & 2,06 & 0,20 \\
\hline Level of competition & 0,98 & 0,94 & 1,31 & 0,60 \\
\hline Regulation & 0,77 & 0,53 & 1,63 & 0,20 \\
\hline Other (Massmart-Leadership position) & 0,42 & 0,74 & - & - \\
\hline
\end{tabular}




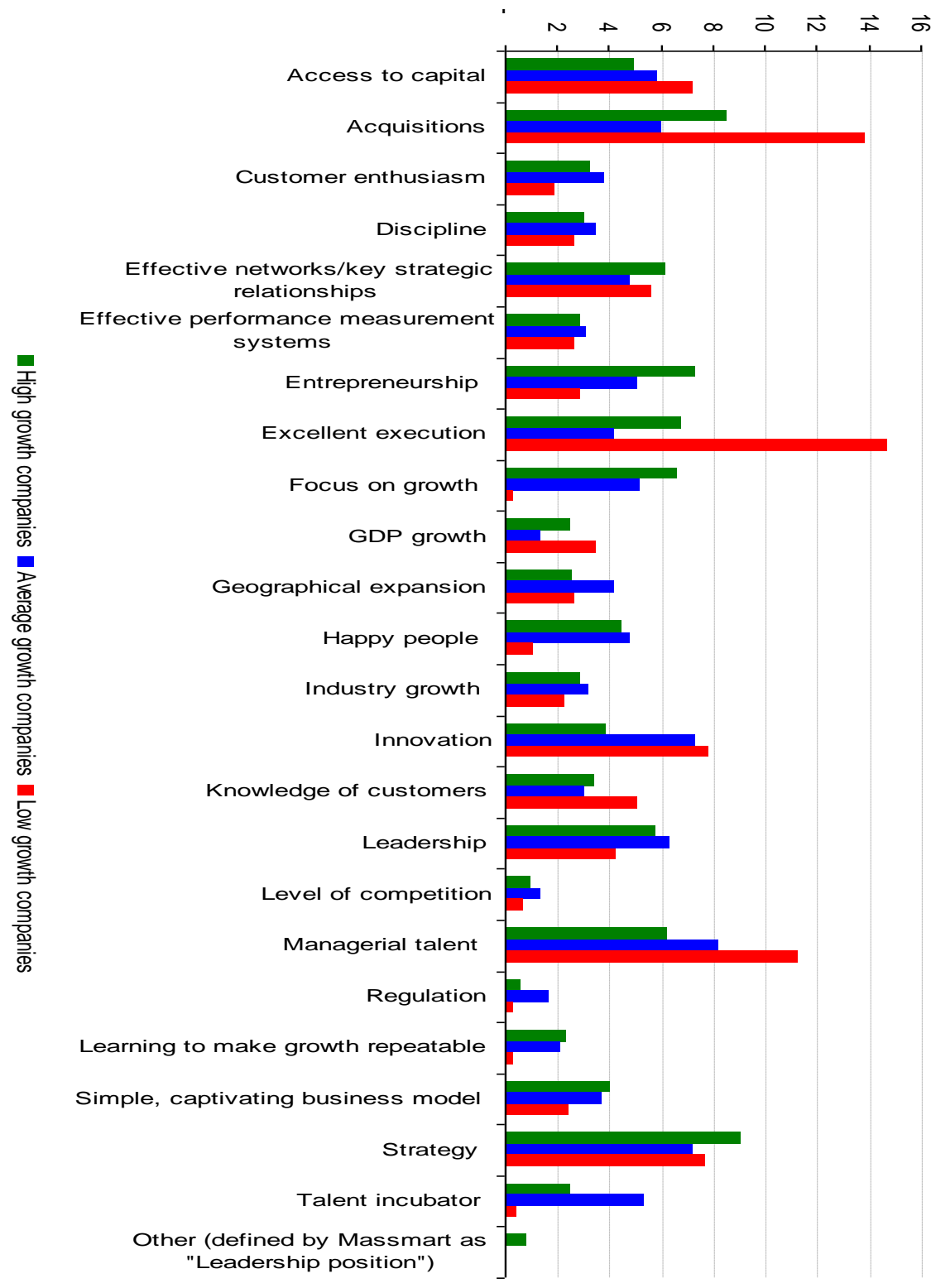

Figure 3: Mean score per growth driver for high, average and low growth companies

Conversely, low growth companies may have less ability to analyse the environment and its inter-relationships with their firm's resources and, therefore, oversimplify it. The second method of quantifying the importance of growth drivers used a multiple regression model to test for significant relationships. In a sense, this model, illustrated in Table 3, was created to support the findings of the survey and ask some further questions relating to variables influencing company growth. The results indicated a significant relationship between growth and the number of years that budget expectations were achieved, as well as between growth and market share growth. The variable, "number of years that budget expectations were achieved", was incorporated in the analysis as a proxy for discipline, possibly underling the importance of operational fitness and its relationships with translating growth opportunities. On the other hand, market share growth was included to further test the importance of this variable and its relationship with industry conditions. Furthermore, companies which achieve market share growth are likely to achieve growth in revenue and earnings.
It would be expected that the performance of the industry subsectors would be linked to company growth rates, however, they were largely ignored by executives. It appears that executives place little emphasis on the growth trend of their particular industry subsector. Perhaps this is a factor of subsectors consisting of firms which are not strictly comparable. Alternatively, it could attest to the fact that executives wish to believe that the growth destiny of their company is more influenced by other factors which they can control, rather than the mere structural characteristics of their particular industry. While the top ranked growth drivers are relatively unsurprising, it is interesting to see the low importance that executives attributed to GDP growth and Industry growth as sustainable growth drivers, particularly in the context of plummeting company growth rates following the global financial crisis and recession which occurred in South Africa in 2008/9. In hindsight these events suggest that companies are more dependent on a buoyant economy than most of the surveyed executives indicated. 
Table 3: Growth variables

\begin{tabular}{|c|c|c|c|c|c|}
\hline Covariate & Coef. & Std. Err. & $\mathbf{t}$ & p-value & $\mathbf{n}$ \\
\hline market_share_2000 & $-0,28$ & 0,20 & $-1,42$ & 0,170 & 25 \\
\hline market_share_2006 & 0,07 & 0,26 & 0,27 & 0,789 & 26 \\
\hline market share difference & 1,08 & $\mathbf{0 , 3 4}$ & 3,21 & 0,004 & 25 \\
\hline revenue_acquisitions & 0,18 & 0,20 & 0,87 & 0,391 & 30 \\
\hline understand_bm & $-0,0002$ & 0,002 & $-0,10$ & 0,918 & 30 \\
\hline growth_forums & 0,01 & 0,09 & 0,11 & 0,917 & 30 \\
\hline pms_growth_focus & $-0,03$ & 0,03 & $-0,86$ & 0,397 & 30 \\
\hline management_levels & $-0,004$ & 0,04 & $-0,13$ & 0,898 & 30 \\
\hline Innovation & 0,01 & 0,17 & 0,03 & 0,975 & 29 \\
\hline years_budget_exp_achieved & 0,06 & $\mathbf{0 , 0 2}$ & 2,79 & 0,009 & 30 \\
\hline staff_turn_over_2000 & 0,15 & 0,55 & 0,27 & 0,787 & 29 \\
\hline staff_turn_over_2006 & $-0,005$ & 0,57 & $-0,01$ & 0,993 & 29 \\
\hline talent_dev_sys & 0,10 & 0,10 & 0,99 & 0,331 & 30 \\
\hline talent_dev_eff & 0,03 & 0,07 & 0,47 & 0,643 & 24 \\
\hline exco_meetings_growth & 0,12 & 0,13 & 0,88 & 0,385 & 30 \\
\hline results_diff_ceo_exco & 0,03 & 0,03 & 0,72 & 0,479 & 30 \\
\hline strategic_partners_dep & $-0,03$ & 0,03 & $-0,96$ & 0,346 & 30 \\
\hline co_key_cust_und & 0,03 & 0,04 & 0,72 & 0,477 & 30 \\
\hline perc_customer_referrals & --- & --- & --- & --- & 25 \\
\hline None & --- & --- & --- & --- & 7 \\
\hline Few & 0,12 & 0,14 & 0,83 & 0,417 & 6 \\
\hline Some & 0,01 & 0,14 & 0,07 & 0,946 & 6 \\
\hline Most & 0,16 & 0,14 & 1,14 & 0,269 & 6 \\
\hline turnover_outside_sa_2000 & $-0,002$ & 0,23 & $-0,01$ & 0,995 & 30 \\
\hline turnover_outside_sa_2006 & 0,13 & 0,22 & 0,60 & 0,553 & 30 \\
\hline ease_access_capital & $-0,02$ & 0,04 & $-0,61$ & 0,545 & 30 \\
\hline Regulations & 0,01 & 0,04 & 0,13 & 0,897 & 30 \\
\hline
\end{tabular}

\section{Strategies}

Six primary growth strategies, identified in the literature review, were amplified by a further eleven growth strategies highlighted by the CEOs of the respondent firms. These 17 growth strategies, illustrated in Table 4, are disaggregated to compare the strategies of high, average and low growth companies. The results suggest high growth companies did not formally develop product development strategies compared to medium and low growth firms. It would also appear as though low growth firms were less likely to develop market intelligence and differentiation strategies. Only high growth companies appeared to formally develop partnership or networks type strategies, as well as specific strategies to align and incentivise the organization for growth. The most common strategies employed across the three groups appeared to be customer-centric, acquisition, adjacent space and fitness strategies. The differential development and use of strategy, illustrated in Figures 4-6, suggests high growth companies might have focused on different strategies compared to their medium and low growth counterparts. High growth companies, for instance, appeared to most commonly incorporate some form of acquisition, adjacent space or fitness strategy followed by some form of partnership and alignment-incentive strategy. Other commonly cited strategies included market intelligence, differentiation or customer centric long term plans.

Medium growth companies, however, most commonly cited the use of adjacent space, product development and fitness strategies followed by acquisition, market intelligence and customer centric strategies.

Finally, low growth companies also cited adjacent space strategies as being the most common followed by acquisition, market intelligence and customer centric strategies. In this regard, their choice of strategy was closer to the medium growth companies than their high growth counterparts. 
Table 4 - Count of growth strategies amongst high, average and low growth companies

\begin{tabular}{|c|c|c|c|}
\hline Growth Strategy & High Growth & Average Growth & Low Growth \\
\hline 1. Customer-centric & 4 & 2 & 2 \\
\hline 2. Product development & - & 3 & 1 \\
\hline 3. Distribution & 1 & 2 & - \\
\hline 4. First mover & 1 & - & - \\
\hline 5. Acquisition & 6 & 2 & 3 \\
\hline 6. Adjacent space & 8 & 4 & 4 \\
\hline 7. Market intelligence & 4 & 2 & - \\
\hline 8. Differentiation & 4 & - & - \\
\hline 9. Fitness & 8 & 3 & 2 \\
\hline 10.Vertical/backward integration & 1 & 1 & - \\
\hline 11.Partnerships & 5 & - & - \\
\hline 12.Cost leadership & 1 & 1 & - \\
\hline 13.Constant re-investment & 2 & 1 & - \\
\hline 14.Risk management & 1 & - & 1 \\
\hline 15.Strong balance sheet & 1 & - & 1 \\
\hline 16.People & 1 & - & - \\
\hline 17.Alignment/incentivize growth & 5 & - & - \\
\hline Total & 53 & 21 & 14 \\
\hline
\end{tabular}

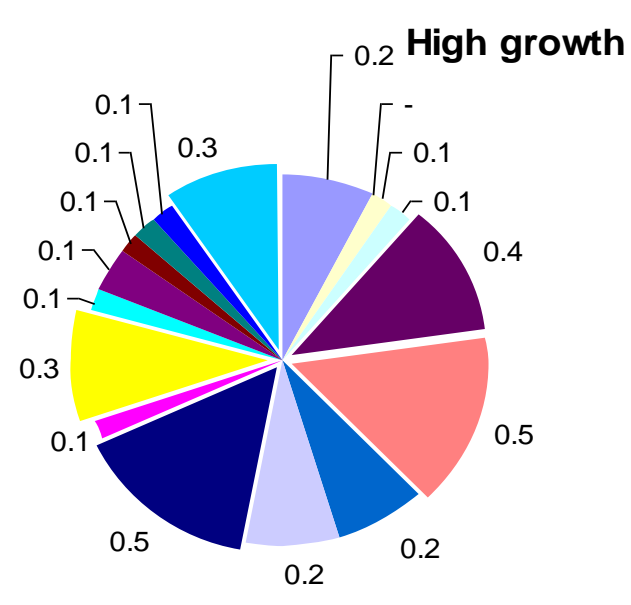

Customer-centric strategy

- Product development strategy

Distribution strategy

First mover strategy

- Acquisition strategy

Adjacent space strategy

- Market intelligence strategy

Differentiation strategy

- Fitness strategy

- Vertical/backward integration strategy

Partnerships strategy

Cost leadership strategy

- Strategy of constant re-investment for growth

- Risk management strategy

- Strong balance sheet for growth

- People strategy

Alignment and incentivisation for growth

Figure 4 - Incidence of growth strategies amongst high growth companies

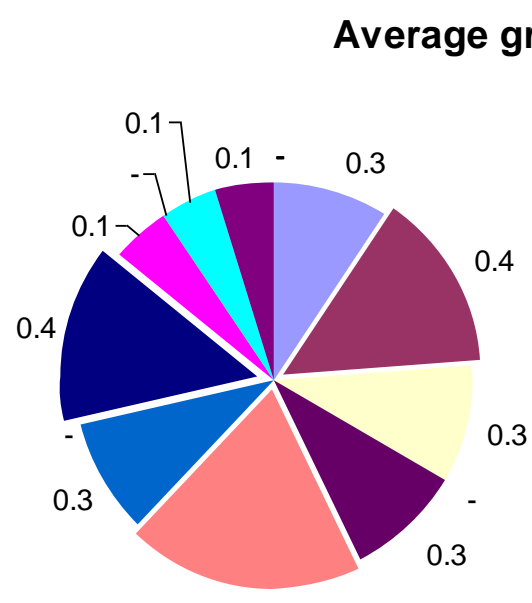

0.5
- Customer-centric strategy

- Product development strategy

Distribution strategy

First mover strategy

- Acquisition strategy

- Adjacent space strategy

- Market intelligence strategy

Differentiation strategy

- Fitness strategy

- Vertical/backward integration strategy

Partnerships strategy

Cost leadership strategy

- Strategy of constant re-investment for growth

- Risk management strategy

- Strong balance sheet for growth

- People strategy

- Alignment and incentivisation for growth

Figure 5 - Incidence of growth strategies amongst average growth companies 


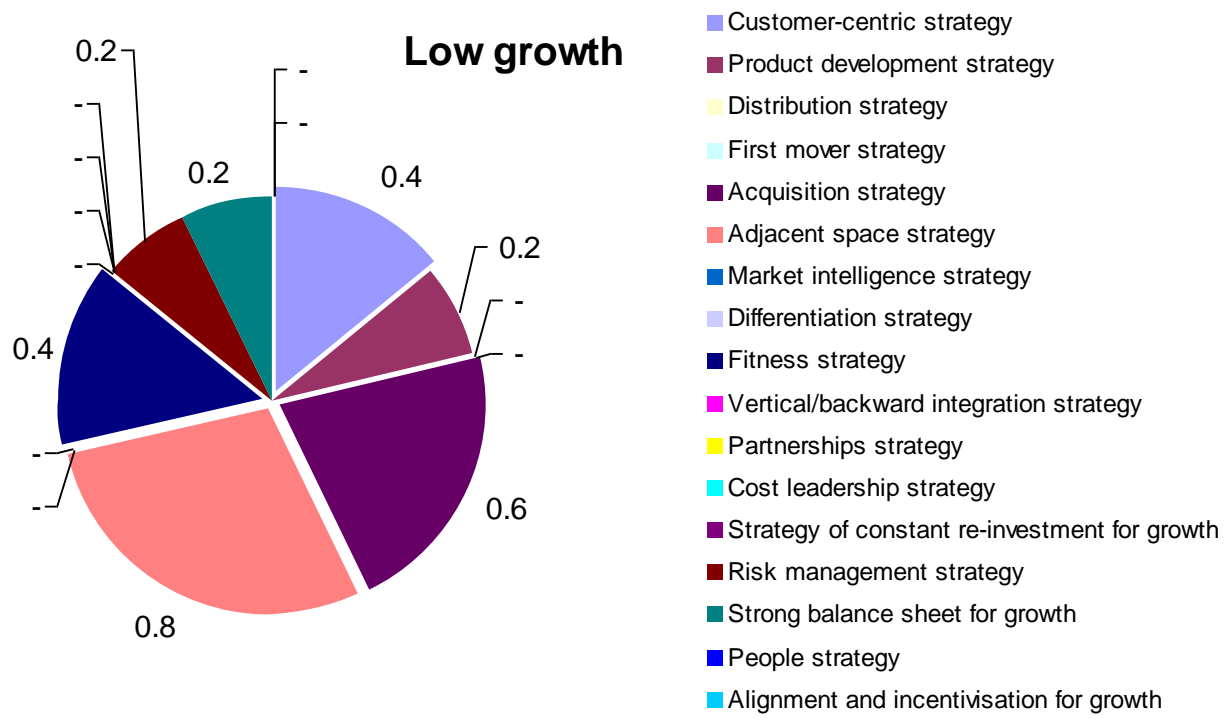

Figure 6 - Incidence of growth strategies amongst low growth companies

The results suggest that high growth companies appear to have adopted a larger variety of strategies than average and low growth companies. In fact, amongst high growth companies, a product development strategy is the only strategy which does not feature, while amongst average growth and low growth companies there are 7 and 10 different strategies respectively which are not mentioned. High growth companies also appear to have adopted strategies that were largely ignored by their medium and low growth counterparts. These observations may be a function of the small sample sizes. They do, however, suggest that more successful companies have formally adopted some different, as well as more multi-faceted plans than medium and low growth firms.

\section{Discussion}

The results suggest high growth companies cited more growth variables, as well as adopted a wider range of formal strategies than their less successful rivals indicating a superior understanding of complex competitive environments and the need to formally plan for variables that influence growth. High growth companies, for example, not only appear to cite partnerships as a major growth variable, but also develop formal plans to cultivate these arrangements. By contrast, medium and low-growth companies may cite partnerships as an important growth variable but do not necessarily develop formal plans to optimise these arrangements. Porter (1990; 2001) cites an organization's relationship with suppliers as a vital component of competitive advantage and developing partnerships essentially reduces upstream costs, as well as access to other opportunities. Kroeger et al. (2000) also indicate that potential partners are attracted by growth suggesting that the formation of partnerships and networks are multi-faceted. Similarly, only high growth companies cite the importance of a happy workforce, managerial talent and talent incubation, as well as develop strategies to align and incentivise management and employees. Conversely, medium growth companies stress the importance of happy people and talent incubation but do not necessarily develop formal plans to achieve this goal. Low growth companies, by contrast, did not rate talent incubation and the presence of happy staff very highly as a growth variable, thus appearing to ignore these resources as a strategic asset that provides a competitive advantage (Slater, 1980; Hamel, 2000; Barringer \& Jones, 2004; Diong \& Choo, 2008).

By contrast, innovation was rated very highly as a growth variable by medium and low growth firms, as well as formally incorporated as a formal strategy. Quite surprisingly, high growth firms rated it as a less important growth variable and did not develop formal innovation strategies contradicting Kelly and Litman (2006) who regard innovation as the "most important ingredient in any modern economy". According to Kaplan and Norton (1992, 2004, 2007), product development and innovation may be a longer term indicator of performance. The relatively short study period in this research may explain why this strategy is not more closely associated with high growth companies.

Acquisitions were cited across the board as a very important growth variable, as well as an important strategy by all the respondents (Hay \& Liu, 1998; Bruner, 2001; Mascarenhas et al., 2002). Empirical evidence, however, indicates acquisitions can both create, as well as destroy wealth. Low growth companies, in particular, cited acquisitions as a key growth variable/strategy, possibly underlining the dangers of acquisitions and/or the poor management thereof (Laurie et al., 2006). Quite surprisingly, none of the respondents cited organic growth as a formal strategy despite its superior ability to achieve growth (Jonash, 2005). The central importance of creating an entrepreneurial organization culture was also not articulated as a formal strategy despite its importance being recognized by high and medium growth companies (Zook 2004; Moreno \& Casillas, 2008). Low growth companies neither ranked entrepreneurship as especially important nor developed specific strategies to incubate this talent.

The importance of operational efficiency and strategy execution was highly cited as both a growth variable and a 
fitness strategy. Low growth companies, however, appeared to ignore the relationship between efficiency and a specific strategy to promote alignment and incentives, thus possibly ignoring the important need to communicate growth programs via a performance measurement system (Kaplan \& Norton, 1992; 2007). A fitness strategy, however, entailing the promotion of operational efficiency was cited across the three categories and may be the most obvious strategy in a modern competitive environment that requires growth in an efficiency context. As a result, it is a strategy which is commonly referred to, but is questionable whether many firms achieve the flexibility and resilience that should be associated with the effective implementation of this strategy.

\section{Conclusion}

The paper developed a practical conceptual framework that outlined the categories of growth driver and strategy that could influence sustainable growth. This framework guided a survey of JSE listed companies that followed an inductive type of approach to explore the causality of growth. The results of the research questions confirm the complex nature of this phenomenon, as well as provide a number of useful insights into growth drivers and strategies for growth.

The first research question investigated the ratio of high growth companies to low growth companies over the study period. The results indicated that $28,2 \%$ of companies achieved an average CAGR in excess of $25 \%, 38,6 \%$ of companies achieved an average CAGR of between $10 \%$ and $25 \%$ and $33,2 \%$ achieved growth of less than $10 \%$. In general, therefore, a very high proportion of JSE-listed companies achieved high growth over the study period (2000-2006) that was one of the contributing factors to the bull market enjoyed on the JSE until the end of 2007. One of the key features of the study period is that it represented a time of economic growth, strong stock market performance and, especially in the latter part of the study, a period of growing consumer spending. The increase in consumer spending was, in part, attributable to increasing levels of disposable incomes, but was also a factor of easily available credit, which enabled consumers to increase consumption ahead of their increases in disposable income. The study period saw the continued commodity super-cycle, and generally strong economic growth globally, but especially in developing markets.

The second research question examined whether specific variables (growth drivers) characterised high growth JSElisted companies. The most highly ranked variables across all the growth categories included acquisitions, managerial talent, operational efficiency, entrepreneurial flair and excellent partnerships. While no conclusive statistical relationships were established, high and low growth companies appeared to rank a number of growth variables very differently. These included the importance of managerial talent, the importance of operational efficiency, the level of entrepreneurial focus, innovation, a happy workforce and a formal focus on growth. High growth companies, moreover, cited a wider range of growth variables than low growth companies, however, all company CEO's seemed to ignore the impact of exogenous variables like the buoyancy of the economy and industry wide effects influencing supply and demand. In this regard, they appear to have overstated the ability of a firm to manage its growth path independent of this influence.

The third research question enquired whether high growth companies had different strategies to low growth companies. The results indicated some similarities with the second research question underling the fact that high growth firms appeared to favour a greater range of strategies than low growth firms. Furthermore, high growth firms were more likely to have developed a strategy that directly supported their ranking of a range of growth variables. For example, only high growth firms developed strategies to align and incentivise the organization in support of their contention that managerial talent, an effective performance measurement system and a happy workforce were vital ingredients of sustained growth. High growth companies, moreover, were the only respondents to stress the importance of partnerships, as well as develop specific partnership strategies. The results also support the contention that acquisitions can create, as well as destroy wealth. Finally, the results suggest that the development of strategy is a complex exercise and that high growth companies appear to develop a more extensive suite of strategies that are built around operational efficiency. .

\section{References}

Ansoff, H. I. 1968. Corporate strategy. Middlesex, England: Penguin Books.

Barney, J.B. 1995. Gaining and sustaining competitive advantage. $2^{\text {nd }}$ Edition. Upper Saddle River. Prentice Hall.

Barringer, B.R. \& Jones, F.F. 2004. 'Achieving rapid growth: revisiting the managerial capacity problem', Journal of Developmental Entrepreneurship, 9(1): 72 -86.

Barringer, B.R., Jones, F.F. \& Lewis, P.S. 1998. 'A qualitative study of the managerial practices of rapid growth firms and how rapid growth firms mitigate the managerial capacity problem', Journal of Developmental Entrepreneurship, 3: 97-122.

Brown, T.E., Davidson, P. \& Wiklund, J. 2001. 'An operationalisation of Stevenson's conceptualisation of entrepreneurship as opportunity-based firm behaviour', Strategic Management Journal, 22: 953 - 968.

Bruner, R.F. 2002. 'Does M\&A pay? A survey of evidence for the decision-maker', Journal of Applied Finance, 12 (1): 48-68.

Cohn, J.M., Khurana, R. \& Reeves, L. 2005. 'Growing talent as if your business depended on it', Harvard Business Review, 83(10): 62-70

Collins, J. 2001. Good to great. Why some companies make the leap and others don't. New York. HarperCollins Publishers.

Covin, J.C., Slevin, D.P. \& Covin, T.J. 1990. Content and performance of growth seeking strategies: A comparison of 
small firms in high- and low-technology industries', Journal of Business Venturing, 5: 391 - 412.

Department of Agriculture and Land Reform. Directorate Agricultural Economics. Sub-directorate Economics and Statistics. 2008. Gross domestic product: Contribution of different industries and sectors towards GDP with reference to the agricultural sector. Pretoria: DALR.

Diong, A. \& Choo, D. 2008. 'Transformative innovation for growth', Industrial Management, May/June 2008: 8 - 11 .

Gertz, D.L. \& Baptista, J.P.A. 1995. Grow to be great: Breaking the downsizing cycle. New York: Free Press.

Hamel, G. 2000. Leading the revolution. Harvard Business School Press.

Harvard Management Update, No. U9606B 1996. 'The latest thinking on growth.

Hay, D.A. \& Liu, G.S. 1998. 'When do firms go in for growth by acquisitions?' Oxford Bulletin of Economics and Statistics, 60(2):143 - 164.

Hess, E.D. 2007. The road to organic growth. How great companies consistently grow market share from within. New York: McGraw-Hill.

Huyett, W.I. \& Viguerie, S.P. 2005. 'Extreme competition', McKinsey Quarterly, Issue 1: 46 - 57.

Iudanov, A. 2007. 'Fast-growing firms and the evolution of the Russian economy', Problems of Economic Transitions, 50(8): 7-28.

Jarillo, J.C. 1989. 'Entrepreneurship and growth: The strategic use of external resources', Journal of Business Venturing, 4: $133-147$.

Joachimsthaler, E. 2007. 'Room to grow', Marketing Management, November/December: $39-44$.

Jonash, R.S. 2005. 'Driving sustainable growth and innovation: Pathways to high performance leadership', Handbook of Business Strategy, 6 (1): 197 - 202.

Kanter, R.M. 2006. 'Innovation: The classic traps', Harvard Business Review, 84(11): 72 - 83.

Kaplan, R.S. \& Norton, D.P. 2007. 'Using the balanced scorecard as a strategic weapon', Harvard Business Review, July-August: $150-161$.

Kaplan, R.S. \& Norton, D.P. 2004. 'Measuring the strategic readiness of intangible assets', Harvard Business Review, February: 52-63.

Kaplan, R.S. \& Norton, D.P. 1992. 'The balanced scorecard - measures that drive performance', Harvard Business Review, January-February: 71-70.
Kelley, T. \& Littman, J. 2006. The ten faces of innovation: Strategies for heightening creativity. London: Profile Books.

Kroeger, F., Traem, M. \& Rockenhaeuser, J. 2000. 'The value growers: Achieving competitive advantage through long-term growth and profits', [online] URL:http://www.atkearney.com/main.taf?p=5,1,1,110,2. Laurie, D.L., Doz, Y.L. \& Sheer, C.P. 2006. 'Creating new growth platforms', Harvard Business Review, 84 (5): 80 -90.

Leedy, P.D. \& Ormrod, J.E. 2001. Practical research: Planning and design. $7^{\text {th }}$ Edition. Upper Saddle River: Merrill Prentice Hall.

Lenth, R.V. 2001. 'Some practical guidelines for effective sample size determination', The American Statistician, 5(3): 187-193.

Mascarenhas, B., Kumaraswamy, D.D. \& Baveja, A. 2002. 'Five strategies for rapid firm growth and how to implement them', Managerial and Decision Economics, 23: 317-330.

McGrath, R.G. \& MacMillan, I.C. 2005. 'Market-busting: Strategies for exceptional business growth', Harvard Business Review, 83(3): 83-89.

Moreno, A.M. \& Casillas, J.C. 2008. 'Entrepreneurial orientation and growth of SMEs: A causal model', Entrepreneurship: Theory and Practice, May: 507-528.

Penrose, E. 1959. The theory of the growth of the firm. New York: John Wiley and Sons.

Perren, L. 1999a. 'Factors in the growth of micro-enterprises (Part 1): Developing a framework', Journal of Small Business and Enterprise Development, 6(4): 367-385.

Perren, L. 1999b. 'Factors in the growth of microenterprises (Part 2): Exploring the implications', Journal of Small Business and Enterprise Development, 7(1): 59-68.

Pirow, P.C. 1990. How to do business research. Johannesburg: Juta Publishers.

Porter, M. 1990. The competitive advantage of nations. New York. Free Press.

Porter, M. 2001. 'Strategy and the Internet', Harvard Business Review, 79 (3): 62-78.

Poulos, N. 2006. 'Owner-manager strategies for growth beyond the micro-business stage'. Management thesis, MCom, University of the Witwatersrand, Johannesburg, June 2006.

Pugh, S.D., Dietz, J., Wiley, J.W. \& Brooks, S.M. 1993. 'Driving service effectiveness through employee-customer linkages', The Academy of Management Executive, 16(4): 73-84

Reichheld, F.F. 2003. 'The one number you need to grow', Harvard Business Review, 81(12): 46 - 54. 
Rijamampianina, R., Abratt, R. \& February, Y. 2003. 'A framework for concentric diversification through sustainable competitive advantage', Management Decision, 41(4): 362 371.

Rumelt, R. 1984. 'Toward a strategic theory of the firm.' In Lamb, R. (ed.). Competitive strategic management. Upper Saddle River. Prentice Hall.

Salojarvi, S., Furu, P. \& Sveiby, K. 2005. 'Knowledge management and growth in Finnish SMEs', Journal of Knowledge Management, 9(2): 103 - 122.

Slater, M. 1980. 'The managerial limitation to the growth of firms', The Economic Journal, 90: 520-528.

Smit, S., Thompson, C. \& Viguerie, P. 2005. 'The do-or-die struggle for growth', McKinsey Quarterly, 3: 34-45.

Stevenson, H.H. \& Jarillo, J.C. 1990. 'A paradigm of entrepreneurship: Entrepreneurial management', Strategic Management Journal, 11: 17-27.

Stewart, T.A. 2006. 'Growth as a process', Harvard Business Review, 84(6): 60 -70.

Zook, C. 2004. 'Increasing the odds of successful growth: The critical prelude to moving "Beyond the Core" ', Strategy and Leadership, 32(4): 17-23.

Zook, C. \& Allen, J. 2003. 'Growth outside the core', Harvard Business Review, 81(12): 66-73. 
Appendix 1 - Sample companies

\begin{tabular}{|c|c|}
\hline Company & Subsector \\
\hline AdVTechol & Specialised Consumer Services \\
\hline Afrox & Specialty Chemicals \\
\hline Argent & Diversified Industrials \\
\hline Aspen & Pharmaceuticals \\
\hline Bell & Commercial Vehicles \& Trucks \\
\hline Bidvest & Business Support Services \\
\hline Cadiz & Investment Services \\
\hline Cashbuild & Home Improvement Retailers \\
\hline Comair & Airlines \\
\hline Dawn & Building Materials \& Fixtures \\
\hline Digicore & Electronic Equipment \\
\hline Ellerines & Home Improvement Retailers \\
\hline $\mathrm{EOH}$ & Computer Services \\
\hline Excellerate & Business Support Services \\
\hline Grindrod & Marine Transportation \\
\hline Iliad & Industrial Suppliers \\
\hline Imperial & Transportation Services \\
\hline Jasco & Electrical Components \& Equipment \\
\hline JD Group & Home Improvement Retailers \\
\hline Massmart & Broadline Retailers \\
\hline Merchant Industrial Property & Real Estate Holding \& Development \\
\hline Metorex & General Mining \\
\hline Murray \& Roberts & Heavy Construction \\
\hline Netcare & Health Care Providers \\
\hline Omnia & Specialty Chemicals \\
\hline Spescom & Computer Services \\
\hline Trencor & Transportation Services \\
\hline UCS & Software \\
\hline Verimark & Broadline Retailers \\
\hline WBHO & Heavy Construction \\
\hline
\end{tabular}


Appendix 2 - Average subsector CAGR

\begin{tabular}{|c|c|c|c|c|c|c|c|}
\hline \multicolumn{8}{|l|}{ AVERAGE SUBSECTOR GROWTH RATES } \\
\hline SUBSECTOR & $\begin{array}{c}\text { CAGR - } \\
\text { REVENUE }\end{array}$ & $\begin{array}{l}\text { CAGR - } \\
\text { EARNINGS }\end{array}$ & $\begin{array}{c}\text { AVERAGE } \\
\text { REVENUE \& } \\
\text { EARNINGS } \\
\text { CAGR }\end{array}$ & $\begin{array}{c}\text { NUMBER OF } \\
\text { HIGH } \\
\text { GROWTH } \\
\text { COMPANIES }\end{array}$ & $\begin{array}{l}\text { NUMBER OF } \\
\text { AVERAGE } \\
\text { GROWTH } \\
\text { COMPANIES }\end{array}$ & $\begin{array}{c}\text { NUMBER OF } \\
\text { LOW } \\
\text { GROWTH } \\
\text { COMPANIES }\end{array}$ & $\begin{array}{l}\text { NUMBER OF } \\
\text { EXCLUDED } \\
\text { COMPANIES }\end{array}$ \\
\hline Equity Investment Instruments & $74.1 \%$ & $69.2 \%$ & $71.7 \%$ & 3 & - & 1 & 6 \\
\hline Marine Transportation & $43.2 \%$ & $56.0 \%$ & $496 \%$ & 1 & - & - & - \\
\hline Steel & $9.1 \%$ & $70.0 \%$ & $396 \%$ & 2 & - & - & - \\
\hline Home Improvement Retailers & $22.2 \%$ & $50.4 \%$ & $363 \%$ & 3 & 1 & - & 1 \\
\hline General Mining & $24.9 \%$ & $42.6 \%$ & $338 \%$ & 6 & 3 & 1 & 7 \\
\hline Furnishings & $38.4 \%$ & $28.4 \%$ & $33.4 \%$ & 1 & - & - & - \\
\hline Business Support Services & $14.1 \%$ & $52.1 \%$ & $33.1 \%$ & 3 & - & - & 2 \\
\hline Pharmaceuticals & $23.2 \%$ & $40.9 \%$ & $32.1 \%$ & 1 & - & - & 1 \\
\hline Computer Hardware & $18.0 \%$ & $38.1 \%$ & $28.1 \%$ & 1 & 1 & - & - \\
\hline Commercial Vehicles \& Trucks & $8.5 \%$ & $44.4 \%$ & $26.4 \%$ & 1 & 1 & - & - \\
\hline Electronic Equipment & $15.3 \%$ & $36.3 \%$ & $258 \%$ & 1 & 1 & 1 & 2 \\
\hline Software & $34.4 \%$ & $17.1 \%$ & $25.7 \%$ & 1 & - & - & - \\
\hline Real Estate Holding \& Development & $15.2 \%$ & $35.6 \%$ & $25.4 \%$ & 5 & 3 & 6 & 18 \\
\hline Specialty Retailers & $17.8 \%$ & $31.8 \%$ & $248 \%$ & 1 & 1 & - & 1 \\
\hline Life Insurance & $16.7 \%$ & $25.6 \%$ & $236 \%$ & - & 3 & 1 & 3 \\
\hline Trucking & $3.3 \%$ & $43.1 \%$ & $232 \%$ & - & 1 & - & - \\
\hline Mobile Telecommunications & $27.6 \%$ & $18.4 \%$ & $230 \%$ & 1 & 1 & - & - \\
\hline Consumer Electronics & $18.6 \%$ & $27.0 \%$ & $228 \%$ & 1 & 1 & - & - \\
\hline Specialty Chemicals & $7.7 \%$ & $37.1 \%$ & $22.4 \%$ & 1 & 1 & 2 & - \\
\hline Health Care Providers & $21.6 \%$ & $22.7 \%$ & $22.1 \%$ & 1 & 1 & - & - \\
\hline Transportation Services & $18.5 \%$ & $25.5 \%$ & $220 \%$ & 2 & 2 & - & 1 \\
\hline Gambling & $16.4 \%$ & $27.1 \%$ & $21.7 \%$ & - & 2 & - & 1 \\
\hline Broadline Retailers & $18.9 \%$ & $24.1 \%$ & $215 \%$ & 2 & 2 & 2 & - \\
\hline Industrial Suppliers & $22.3 \%$ & $20.3 \%$ & $213 \%$ & 1 & 1 & 1 & - \\
\hline Industrial Machinery & $18.6 \%$ & $23.6 \%$ & $21.1 \%$ & 1 & 3 & - & 1 \\
\hline Apparel Retailers & $9.6 \%$ & $30.3 \%$ & $199 \%$ & 1 & 2 & 2 & - \\
\hline Asset Managers & $20.8 \%$ & $18.2 \%$ & $195 \%$ & - & 1 & - & 2 \\
\hline Integrated Oil \& Gas & $21.4 \%$ & $17.2 \%$ & $193 \%$ & - & 1 & - & - \\
\hline Building Materials \& Fixtures & $13.6 \%$ & $23.8 \%$ & $18.7 \%$ & 1 & 4 & 1 & 3 \\
\hline Property \& Casualty Insurance & $15.9 \%$ & $21.2 \%$ & $186 \%$ & 1 & 2 & - & - \\
\hline Containers \& Packaging & $15.9 \%$ & $19.1 \%$ & $175 \%$ & 2 & 1 & 1 & - \\
\hline Distillers \& Vintners & $20.9 \%$ & $14.1 \%$ & $175 \%$ & - & 1 & - & 1 \\
\hline Waste \& Disposal Services & $14.4 \%$ & $18.5 \%$ & $16.4 \%$ & - & 1 & - & 1 \\
\hline Food Retailers \& Wholesalers & $13.7 \%$ & $18.9 \%$ & $163 \%$ & - & 2 & - & 2 \\
\hline Farming \& Fishing & $12.7 \%$ & $15.6 \%$ & $142 \%$ & 2 & 1 & 5 & 3 \\
\hline Banks & $13.1 \%$ & $14.7 \%$ & $139 \%$ & 2 & 2 & 2 & 2 \\
\hline Nonferrous Metals & $14.7 \%$ & $12.0 \%$ & $13.4 \%$ & - & 1 & - & 4 \\
\hline Auto Parts & $3.3 \%$ & $23.1 \%$ & $132 \%$ & - & 3 & - & - \\
\hline Broadcasting \& Entertainment & $8.8 \%$ & $17.2 \%$ & $130 \%$ & 1 & 1 & 1 & - \\
\hline Consumer Finance & $8.9 \%$ & $16.9 \%$ & $129 \%$ & - & 1 & - & 2 \\
\hline Platinum \& Precious Metals & $15.3 \%$ & $10.0 \%$ & $126 \%$ & - & 4 & - & 6 \\
\hline Diversified Industrials & $14.5 \%$ & $9.9 \%$ & $122 \%$ & 1 & 1 & 2 & 1 \\
\hline Electrical Components \& Equipment & $3.2 \%$ & $20.7 \%$ & $119 \%$ & - & 2 & 2 & 1 \\
\hline Publishing & $(1.4 \%)$ & $22.2 \%$ & $10.4 \%$ & 1 & - & 1 & 1 \\
\hline Hotels & $9.7 \%$ & $8.8 \%$ & $93 \%$ & - & 1 & 1 & 1 \\
\hline Restaurants \& Bars & $8.5 \%$ & $8.7 \%$ & $86 \%$ & - & 1 & 2 & - \\
\hline Food Products & $5.9 \%$ & $10.8 \%$ & $83 \%$ & - & 2 & 2 & - \\
\hline Heavy Construction & $8.1 \%$ & $7.2 \%$ & $76 \%$ & 1 & 3 & 2 & 5 \\
\hline Investment Services & $(1.1 \%)$ & $10.4 \%$ & $76 \%$ & 1 & 1 & 3 & 8 \\
\hline Forestry \& Paper & $17.4 \%$ & $(4.1 \%)$ & $6.7 \%$ & 1 & - & 1 & 3 \\
\hline Gold Mining & $19.0 \%$ & $(7.6 \%)$ & $5.7 \%$ & - & 3 & 2 & 10 \\
\hline Airlines & $12.4 \%$ & $(5.5 \%)$ & $35 \%$ & - & - & 1 & - \\
\hline Specialty Finance & $16.1 \%$ & $(13.6 \%)$ & $13 \%$ & 1 & - & 1 & 3 \\
\hline Computer Services & $4.2 \%$ & $(1.8 \%)$ & $12 \%$ & 1 & 4 & 9 & 1 \\
\hline Clothing \& Accessories & $(11.1 \%)$ & $10.8 \%$ & $(02 \%)$ & - & 1 & 4 & - \\
\hline Business Training \& Employment Agencies & $8.2 \%$ & $(9.6 \%)$ & $(0.7 \%)$ & - & 1 & 1 & 1 \\
\hline Diamonds \& Gemstones & $(16.5 \%)$ & $11.8 \%$ & $(2.4 \%)$ & - & 1 & 2 & 3 \\
\hline Travel \& Tourism & $(2.0 \%)$ & (3.3\%) & $(2.7 \%)$ & - & - & 2 & - \\
\hline Brewers & $(23.6 \%)$ & $(26.2 \%)$ & $(24.9 \%)$ & - & - & 2 & - \\
\hline Coal & Insufficient inf & formation & & - & - & - & 2 \\
\hline Recreational Services & Insufficient inf & formation & & - & - & - & 1 \\
\hline Real Estate Investment Trusts & Insufficient inf & formation & & - & - & - & 5 \\
\hline Insurance Brokers & Insufficient inf & formation & & - & - & - & 1 \\
\hline Automobiles & Insufficient inf & formation & & - & - & - & 1 \\
\hline Financial Administration & Insufficient inf & formation & & - & - & - & 1 \\
\hline Fixed Line Telecommunications & Insufficient inf & formation & & - & - & - & 1 \\
\hline TOTALS & & & & 57 & 78 & 67 & 120 \\
\hline
\end{tabular}

